\title{
VALUES ORIENTED LEADERSHIP - CONCEPTUALIZATION AND PRELIMINARY RESULTS IN SLOVAKIA
}

\author{
Anna LAŠÁKOVÂ ${ }^{1}$, Lubica BAJZÍKOVÁ ${ }^{2}$, Ivana BLAHUNKOVÁ ${ }^{3}$ \\ Faculty of Management, Comenius University in Bratislava, Bratislava, Slovakia \\ E-mails: ${ }^{1}$ anna.lasakova@fm.uniba.sk (corresponding author); \\ ${ }^{2}$ lubica.bajzikova@fm.uniba.sk; ${ }^{3}$ ivana.blahunkova@gmail.com
}

Received 09 December 2018; accepted 18 February 2019

\begin{abstract}
The paper builds on the current trend in scholarly literature that reflects leadership from an ethical perspective. It introduces a new conceptualization of the values oriented leadership (VOL) and based on results of a pilot study, it informs on the level of VOL in the Slovak business environment and on systematic differences in VOL related to multiple individual and organizational factors. Contrary to the literature, results show that the VOL does not differ substantially between female and male leaders. Furthermore, this study adds to the current leadership ethics research also in that it includes two rarely investigated factors - the "length of leader-follower cooperation" and the "frequency of leader-follower interaction". Both show an effect on the perceived VOL level; the theorized positive correlation with the frequency of leader-follower interaction is confirmed, nevertheless, somewhat surprisingly, results imply that the length of leader-follower cooperation affects negatively leader's perceived ethicality at work. This study proves also differences in VOL based on regional company location and company size, with leaders in small companies rated significantly lower in VOL than leaders in large companies. The difference in VOL between leaders in Slovak-owned and foreign-owned companies is not established. Yet, compared to the private sector, this study confirms significantly lower VOL in the state-owned companies.
\end{abstract}

Keywords: ethics, leadership, ethical leadership, values, values oriented leadership, Slovakia, CEE.

JEL Classification: M12, M14.

\section{Introduction}

The last economic and financial crisis has been, undoubtedly, a strong impetus for intensifying research within business ethics. Declarations of many prominent authorities in both the political and business environment suggest that this issue needs to be handled with an increased attention. In one of his speeches, the former President of the European Commission, José Manuel Barroso said that "as the financial and economic crisis progresses, it becomes increasingly clear that the moment has come to reconcile economic governance with our fundamental ethical values on which the European project has been based over the last 50 years" (European Commission 2009). Recognized economist Antonio Argandona presented in his seminal paper on the ethical causes of the financial crisis the idea that the crisis is not unique in that it is based on the ethical misconduct of those concerned. Its specificity is that it is a crisis of leadership and, in general, of management in organizations (Argandona 2012).

Thus, to address ethical concerns at the company level requires increasing the ethical awareness of leaders in organizations. Clearly, the workplace plays an important role in forming the moral behaviour of individuals and it is the leaders who are primarily responsible for the level of ethicality in organizations. Leaders have the power to model the behaviour of their colleagues in the field of morality. The literature offers a varied palette of empirically based arguments in this respect. For instance, Trevino et al. (2003) point out that the ethical leadership promotes ethical behaviour of employees in the organization. Based on

Copyright (C) 2019 The Authors. Published by VGTU Press.

This is an Open Access article distributed under the terms of the Creative Commons Attribution License (http://creativecommons.org/licenses/by/4.0/), which permits unrestricted use, distribution, and reproduction in any medium, provided the original author and source are credited.. 
Schein's (2010) work, leaders' behaviour influences followers' behaviour through role modelling in that employees learn, and also somewhat reproduce, the behaviour of their leaders. As Weaver et al. (2005) note, leaders play a major role in shaping ethical behaviour and moral standards of employees. Mayer et al. (2009) argue that ethical leadership is the very foundation of an ethical organizational culture, since ethical leadership stems from the highest places in the organizational structure and positively correlates with the ethical behaviour of lower-ranking managers. Furthermore, Brown and Trevino (2006) assume ethical leadership has a positive impact on ethical decision-making of employees and on their prosocial behaviour, i.e. organizational loyalty; and on the contrary, ethical leadership is negatively correlated with counterproductive employee behaviour. In a similar vein, Avey et al. (2012) show that ethical leadership has a positive influence on employees' sense of well-being and their job satisfaction as leader encourages co-workers to openly express opinions and ideas. Thus, employees under the leadership of an ethical leader are optimistic, self-confident and aware that they have an impact on what is happening in the company. Furthermore, for instance, Wang and Kleiner (2005) discuss on the importance for top management to be ethical role models for decreasing employee unethical behaviour and development of an honest and satisfactory working environment. Bai et al. (2017) propose that ethical leadership fosters an ethical climate that generates a moral context impacting employees' behaviour in teams. According to Uhl-Bien and Carsten (2007) by empowering co-workers, an ethical leader gives them the opportunity to grow morally and employees are thus better prepared to face the unethical behaviour of other managers and business owners. The ethics-oriented communication and behaviour of leaders considerably attract followers' attention (Jordan et al. 2013). Managers should therefore "ask themselves what they can do to make the ethical dimension of their leadership salient in the social context" (Trevino et al. 2003: 30).

This paper builds on the current trend in scholarly literature that reflects the leadership and management from a prosocial humanistic view (e.g., Dierksmeier 2016). While today the leadership ethics discourse is well established in Western Europe and the US, in Slovakia this trend has begun to develop with a certain lag and currently it is still at the brink of scholarly attention. Despite a growing societal demand for higher accountability in leadership work, the values of responsibility and humanism are still somewhat underemphasized in practice. Hence, this study adds to the current debate on leadership ethics and presents a working model of the values oriented leadership together with preliminary results from a pilot study carried out in the Slovak business environment. The main aim is to assess the level of values oriented leadership in companies operating in
Slovakia and to investigate potential significant differences in its level based on multiple individual and organizational factors.

\section{Theoretical underpinnings to the values oriented leadership}

The values oriented leadership (VOL) is based on the idea that the effectiveness of laws and other regulations begins and ends with the ethicality of individual managers and company owners. In addition, it reflects on the fundamental change in understanding what is meant by the "effective leadership" and who is a "successful leader". As discussed in the above outlined Introduction, today it seems that ethical leadership is not just a rhetoric "add-on" of the classical theories of leadership, but it reflects a paradigmatically fundamental change in the scientific discourse in question. This change in the understanding of leadership, and management in general, can be referred to as the "turn to ethics" in leadership. Put differently, this twist in the discourse represents a departure from the traditional "profits-only" mentality and instrumental understanding of the leader as a person whose main task is to achieve success in the form of financial profits. As Schwartz et al. (2005) note, company executives should no longer focus only on maximizing firm performance and corporate governance should no longer be considered distinct from ethics. Considering that VOL associates with the ethical rationality in the work environment, not only the profit but also the ethical way how to achieve this goal is important. Success is then defined as the development and wellbeing of all parties involved, whilst the primary duty of the leader is to make principled and fair decisions in relation to employees and other stakeholders.

As VOL represents a relatively new terrain within ethical leadership studies, to date no systematic approach to its exploration has been established. The scientific discourse is largely fragmented and underdeveloped, while the conceptual ambiguities halt streamlining VOL in practice. This situation is even more problematic due to considerable terminological vagueness in the use of terms such as "values oriented", "values driven", "values centred", and probably their most commonly used alternative, the "values based" leadership. In this context, it is important to note that the term "values oriented" is regarded as a synonym to "values based" leadership in this study. Although there is a slight distinction in the meaning of both words, the literature does not differentiate between the two. Both terms denote the same phenomenon, namely the inclination of leaders to ethical behaviour and decision-making rooted in their strong conviction about the importance of certain ethical principles in the company and in business in general.

In the theory, there are at least three distinct approaches to the respective concept. First, some authors regard values 
oriented (or values based) leadership as a specific style based on particular set of principles that leaders should exemplify through their decisions and behaviour at workplace. For instance, Lebow and Simon (1997) point to eight basic people values for organizations: truth, trust, mentoring, openness, giving credit, risk-taking, honesty, and caring. Kraemer (2011) builds his definition of values based leadership on four principles: self-reflection, balance, self-confidence, and humility.

Second, other portion of the VOL literature uses the term "values oriented/based leadership" as a roof term for various theories focusing on moral, authentic, principled and ethical dimension of leadership (e.g., Berger 2014, Copeland 2014). Thus, the term values based leadership covers concepts like ethical, spiritual, responsible, servant, authentic, transformational, charismatic or paternalistic leadership.

Third, the least populated approach does not specify any particular values in VOL. Instead, this approach explores the underlying processes of VOL, i.e. how ethics is actually conveyed by the values oriented leaders and what types of methods are involved in that. For instance, Prilleltensky (2000) introduces a model of values based leadership that describes the underlying tensions at play between the interests of leaders, workers and communities. Furthermore, he posits that values based leaders need to alleviate these tensions by clarifying values, promoting harmony between values, interests and power, enhancing congruence and confronting people and groups subverting values or abusing power to promote personal interests (Prilleltensky 2000). Based on her corporate experience, Dean (2008) defines the concept as leading by example, that is, ethical role modelling in "doing the right thing for the right reasons and not compromising core principles" (Dean 2008: 3 ).

In line with O'Toole (2008) this study distinguishes VOL from other leadership concepts like the transformational, paternalistic or servant leadership. In accordance with the above discussed first approach, here the VOL is regarded as a distinct style of leading others established on specific principles. Its delineation follows on five prominent theories that directly and explicitly refer to the ethical side of the leadership process, namely the ethical leadership (Trevino et al. 2000, Brown et al. 2005, Brown and Trevino 2006, Kalshoven et al. 2011, Eisenbeiss 2012), spiritual leadership (Fry 2003, Chen and Li 2013), servant leadership (Barbuto and Wheeler 2006, Liden et al. 2008, Sendjaya et al. 2008, Van Dierendonck and Nuijten 2011), authentic leadership (Avolio and Gardner 2005, Gardner et al. 2005a, 2005b, Gardner et al. 2011), and responsible leadership (Maak and Pless 2006, Freeman and Auster 2011, Pless and Maak 2011, Voegtlin et al. 2012).

Furthermore, the VOL delineation builds on several theoretical streams, namely on social learning theory (Bandura
1971), leader-member and social exchange perspective (Graen 1976, Graen and Uhl-Bien 1995), and humanistic management approach (Dierksmeier 2016).

First, according to Trevino and Brown (2005), employees learn what to do, and what not to do, by observing leader's behaviour and its consequences. The social learning perspective points out leaders have a real power to influence others through role modelling and setting an example for others how to behave. By their own behaviour they show to others what are the norms and rules that are expected and desirable.

Second, the leader-member exchange theory suggests that the essence of the leadership process is to build relationships between the leader and the subordinates, while the quality of these relationships will fundamentally affect the responsibilities, decision-making and performance of the subordinates (Deluga 1998). The relationships that leader builds and develops with other people are the basis for mutual trust, respect and positive emotional connection between team members leading to organizational effectiveness (Liden et al. 1997). This implies that followers identify with the leader in case they believe in fairness and honesty of leader's deeds. Leader-member relationship develops over time and must be rooted in trustworthiness of both parties and reciprocity (Trevino and Brown 2005). As a person's sincerity and trustworthiness are mirrored in the consistency in words and deeds, the VOL requires the leader to reflect on own behaviour, to exercise introspection and to be open to feedback, and eventually also critique, from others. In addition, it presupposes a high level of authenticity in the sense of staying truthful to oneself and to own values.

Third, VOL contributes to the humanization of the workplace environment as it represents a departure from the purely instrumental understanding of the leader as somebody whose main aim and responsibility lies in attaining profits (Lašáková et al. 2015, Remišová et al. 2016). As such, VOL implies humanistic understanding of the leader as a humble altruist, who understands the importance of a certain higher sense in life and strives for the (self)development and wellbeing for all relevant stakeholders.

Abstracting from the above discussed theories, the VOL entails five basic elements: leader's self-reflection, consecutive authenticity in decisions and behaviour, influencing others by ethical role modelling, the pursuit of self-development as well as development of others, and altruism in relationship to other people.

The (1) Self-reflection denotes leader's ability of introspection and the will to learn more about oneself, about one's place in society and life, about own abilities and skills. The self-reflection unveils to the leader how he/she interacts with others, how he/she influences them (and how he/she is influenced by others) and what patterns show off in leader's behaviour in different situations (in life or at work). 
The (2) Authenticity relates to the ability of the leader to be himself and at the same time to allow others to be themselves and to freely express their opinion. The authenticity embodies respect for individual differences between people, acceptance of different individuals and their diverse needs or life goals, and promotion of the values of accuracy, truthfulness and verity in interpersonal relations.

Leader as the (3) Role model significantly influences others to follow him. Others want to be like the leader, in that they identify with the leader. Under his/her leadership, people feel they could be successful since the leader serves as an example of how to behave and how to solve workplace problems.

The (4) (Self)Development element implies that the leader cares for personal and professional growth, continuously learns and actively acquires new knowledge serving to both personal and organizational progress. The leader strives to keep up with the recent knowledge in the field. At the same time, he/she tries to induce the same attitude in other people (followers, colleagues, etc.). The leader does not impede the growth of other people at work. On the contrary, the leader encourages them to progress through preparing the best possible conditions, in which they can develop and gain new experiences. Leader closely follows the progress of people and helps them to develop their abilities and skills.

Finally, the (5) Altruism means selflessness and kindness to other people. Leader strives for the well-being of others. In respecting the others, the leader does not reduce others as merely tools to achieve his/her own goals. The leader goes beyond the limits of a cold calculation and is willing to sacrifice own interests or benefits for the good of the others. The leader likes people and actually enjoys working with them. He/she is willing to help others if they are in difficulties.

To build a usable tool to measure the level of VOL in companies, we operationalized the above delineated five VOL components in an initial pool of 70 items, which were consecutively validated and reduced in several follow-up quantitative and qualitative studies (Blahunková 2018). The validation resulted in a 24 -item VOLQ (Values Oriented Leadership Questionnaire). The next section of this paper describes the preliminary results based on the VOLQ and identifies systematic differences in the VOL level in the Slovak business environment based on multiple individual and organizational factors. As this is the first study on VOL in the Slovak business environment, it is exploratory in nature. Instead of positing hypotheses on the relationship between VOL and particular factors, we postulate two broader research questions:

RQ1 What is the level of values oriented leadership in companies operating in Slovakia?

RQ2 Are there any significant differences in the level of values oriented leadership that are related to selected individual and organizational factors?

\section{Methodology}

This pilot study was carried out in spring 2018 as part of a series of validation studies aimed at creating a reliable tool to measure the level of VOL in companies. The sample was convenience-based and in final included 288 individual participants from diverse industries. The call for participation with the link to e-questionnaire was disseminated through various online channels via direct email, social networks and multiple Facebook groups (professional, student, alumni). The final dataset included Slovak respondents who are currently employed and have one direct supervisor (leader).

\subsection{Sample}

The sample $(\mathrm{N}=288)$ entailed $34 \%$ of men and $66 \%$ of women participants. The average age was 31 years with the span from 19 to 60 years. According to educational background, $61 \%$ had university education. Almost $60 \%$ worked in the Bratislava region (region with the capital city). Up to $19 \%$ served at managerial position, whilst the rest of the sample was non-managerial employees. About $66 \%$ were fulltime employees; others were employed on a short-term or casual basis. As for the length of cooperation with a given leader, $20 \%$ of participants worked with the leader less than six months, $51 \%$ worked with the current leader up to three years, $20 \%$ more than three and less than six years, and $10 \%$ worked with a given leader for more than six years. As for the frequency of direct interaction, $67 \%$ had frequent (daily) contact with their leaders, $27 \%$ were interacting occasionally, and $7 \%$ had almost no direct face-to-face contact with the leader. About 83\% participants were of the same nationality as their leader. As to the leaders' gender, 59\% were male managers. From the viewpoint of company size, $13 \%$ of participants worked in micro (up to nine employees) companies, $20 \%$ in small (with up to 49 employees) companies, $40 \%$ in medium size (50-249 employees) companies and $28 \%$ in large companies (with more than 250 employees). The biggest proportion worked in IT/ICT companies (22\%), followed by services in general (13\%), sales \& marketing (12\%) and heavy industry (10\%). Slightly more than $22 \%$ worked in state owned companies, $64 \%$ in Slovak-owned companies, and 63\% worked in companies that were active in markets abroad in export and sales.

\subsection{Scale}

The level of values oriented leadership was measured with VOLQ (Values Oriented Leadership Questionnaire). The VOLQ construct validity was established in several follow-up qualitative and quantitative studies (Blahunková 2018). The initial pool included 70 items. After assessing its face, content, convergent, discriminant and predictive 
Table 1. Descriptive results

\begin{tabular}{|l|c|c|c|c|c|c|c|c|}
\hline & Mean & Std.Dev. & Skew. & Kurt. & 1 & 2 & 3 & 4 \\
\hline 1 Self-reflection & 4.34 & 1.806 & -0.373 & -1.009 & & & & \\
\hline 2 Altruism & 5.03 & 1.615 & -0.676 & -0.589 & $.674^{* *}$ & & & \\
\hline 3 Role model & 4.27 & 1.812 & -0.340 & -1.092 & $.652^{* *}$ & $.670^{* *}$ & & \\
\hline 4 (Self)Development & 4.96 & 1.535 & -0.741 & -0.360 & $.615^{* *}$ & $.678^{* *}$ & $.717^{* *}$ & $.655^{* *}$ \\
\hline 5 Authenticity & 4.76 & 1.579 & -0.539 & -0.770 & $.682^{* *}$ & $.709^{* *}$ & $.636^{* *}$ \\
\hline VOL total & 4.67 & 1.565 & -0.549 & -0.827 & & & & \\
\hline
\end{tabular}

Note: ${ }^{\star \star}$. Correlation is significant at the 0.01 level (2-tailed). Mean values on scale 1 to 7 (Strongly disagree - Strongly agree).

validity, the final scale was reduced to 24 items and demonstrated a very high level of internal consistency with Cronbach's alpha of 0.974 . The exploratory factor analysis with an oblique rotation (direct oblimin) showed that all of the items loaded on one factor that accounted for $63 \%$ of the variance in data.

The VOLQ asks respondents to assess their leaders on a seven-point scale from "strongly disagree" to "strongly agree". Three items regard leader's self-reflection (example: "My leader is able to accept criticism"), three items relate to role modelling (example: "I feel to be a true follower of my leader"), six items consider (self)development (example: "For my leader, my development is one of his/her priorities"), six items regard leader's authenticity (example: "My leader encourages me to tell him/her openly in case I disagree"), and six items relate to leader's altruism (example: "My leader is willing to help me in case I have personal problems").

To address the second research question, we have selected nine factors with varying degree of support in prior literature on the relationship between ethical leadership and individual (demographic) and organizational (company) characteristics. The individual variables employed in this study entailed the (1) leader's gender (female/male), (2) leader-rater nationality (leader and follower share the same/have different nationality), (3) length of experience with the leader (follower works with the leader for less than six months/more than months and less than three years/ more than three years and less than six years/more than six years), (4) leader-rater frequency of interaction (high, i.e. leader and follower are in daily direct contact/medium, i.e. they are in contact occasionally/low, i.e. they interact rarely). The organizational variables included the (5) company location (the company is located in Bratislava region/in other Slovak regions), (6) owner 1 (state/private), (7) owner 2 (Slovak/foreign), (8) international export-sales (yes, the company engages in export or sales internationally/no, the company is not engaged internationally), and (9) company size (micro, with up to nine employees/small, with ten to 49 employees/medium, with 50 to 249 employees/large, with 250+ employees).

\section{Results}

Table 1 shows descriptive results for the overall level of VOL in Slovak companies $(M=4.67)$ and for the individual VOL dimensions, with Altruism scoring the highest $(\mathrm{M}=5.03)$ and Role modelling scoring the lowest $(\mathrm{M}=$ 4.27). Based on Kolmogorov-Smirnov test, data were nonnormally distributed $(\mathrm{p}<0.001)$ and skewed left $(-0.549)$ with a negative kurtosis of lighter-tailed distribution of data (-0.827). According to Kendall's tau-b test, the five VOLQ dimensions are positively correlated, while the $\tau$ varies from 0.615 lowest to 0.717 highest.

In addition, to be able to control for the effect of related variables, partial correlation analysis between VOL and the nine factors was conducted. We have controlled for raters' gender, education level and position in the company (managerial/non-managerial). Table 2 shows the respective results.

Table 2. Correlations between VOL and individual and organizational factors

\begin{tabular}{|l|c|}
\hline \multicolumn{1}{|c|}{ Individual/Organizational Factors } & VOL \\
\hline Leader gender & -0.048 \\
\hline Leader-Rater nationality & 0.002 \\
\hline Length of experience with the leader & $-.255^{* *}$ \\
\hline Leader-Rater frequency of interaction & $-.169^{* *}$ \\
\hline Company location & $-.179^{* *}$ \\
\hline Owner 1 & $.239^{* *}$ \\
\hline Owner 2 & 0.037 \\
\hline International export-sales & $-.293^{* *}$ \\
\hline Company size & 0.027 \\
\hline
\end{tabular}

Note: ${ }^{* *}$. Correlation is significant at the 0.01 level (2-tailed).

Due to the non-normal distribution of data, MannWhitney test (for comparing two groups) and KruskalWallis test (for comparing three or more groups) were used to identify the significant differences in the sample (see Table 3).

Results (Table 3) indicate significant differences in the values oriented leadership level in six out of the nine 
Table 3. Significant differences in VOL between groups

\begin{tabular}{|l|c|l|}
\hline $\begin{array}{c}\text { Individual/Organi- } \\
\text { zational Factors }\end{array}$ & $\begin{array}{c}\text { Asymp. } \\
\text { Sig. }\end{array}$ & \multicolumn{1}{|c|}{$\begin{array}{c}\text { VOL mean } \\
\text { between groups }\end{array}$} \\
\hline Leader gender & 0.415 & $\begin{array}{l}4.74-4.58 \\
\text { Male/Female }\end{array}$ \\
\hline $\begin{array}{l}\text { Leader-Rater } \\
\text { nationality }\end{array}$ & 0.797 & $\begin{array}{l}4.67-4.68 \\
\text { Same/Different }\end{array}$ \\
\hline $\begin{array}{l}\text { Length of experien- } \\
\text { ce with the leader }\end{array}$ & 0.000 & $\begin{array}{l}5.24-4.69-4.69-3.53 \\
<6 \mathrm{~m} / 6 \mathrm{~m}-3 \mathrm{y} / 3 \mathrm{y}-6 \mathrm{y} / \mathrm{6y}\end{array}$ \\
\hline $\begin{array}{l}\text { Leader-Rater } \\
\text { frequency of } \\
\text { interaction }\end{array}$ & 0.001 & $\begin{array}{l}4.87-4.28-4.24 \\
\text { High/Medium/Low }\end{array}$ \\
\hline Company location & 0.004 & $\begin{array}{l}4.90-4.33 \\
\text { Bratislava region/Other } \\
\text { regions }\end{array}$ \\
\hline Owner 1 & 0.000 & $\begin{array}{l}3.97-4.87 \\
\text { State/Private }\end{array}$ \\
\hline Owner 2 & 0.509 & $\begin{array}{l}4.60-4.87 \\
\text { Slovak/Foreign }\end{array}$ \\
\hline $\begin{array}{l}\text { International } \\
\text { export-sales }\end{array}$ & $\begin{array}{l}5.03-4.08 \\
\text { Yes/No }\end{array}$ \\
\hline Company size & $\begin{array}{l}5.11-4.09-4.74-4.80 \\
\text { Micro/Small/Medium/Large }\end{array}$ \\
\hline
\end{tabular}

Note: VOLQ Mean values on scale 1 to 7 (Strongly disagree Strongly agree).

examined factors. As to the individual factors, the gender of the assessed leader does not have any relationship with the rater's perception of the respective leader $(\mathrm{p}=0.415)$. Similarly, the level of VOL is not dependent on whether or not the leader and the follower share the same nationality ( $\mathrm{p}$ $=0.797$ ). Length of experience with the leader significantly influences VOL perceptions in that the longer respondents work with the leader, the less they perceive their superior as a values oriented leader $(p=0.000)$. The mean value for employees who work with the assessed leader less than six months is $M=5.24$, while those who work with the leader longer (more than six months and less than three years, and more than three years and less than six years) rate their leader somewhat lower in VOL $(\mathrm{M}=4.69$ for both groups). People working with a given leader for more than six years ascribe the leader the lowest VOL score with $\mathrm{M}=$ 3.53. Furthermore, the frequency of interaction between the follower and the leader influences the level of perceived VOL, too $(p=0.001)$. Leaders who are in daily face-to-face contact with followers are evaluated more favourably $(\mathrm{M}=$ 4.87), whilst a somewhat lower preference is given to leaders who are in just an occasional contact with their followers $(\mathrm{M}=4.28)$. The lowest VOL is attributed to leaders with rare interaction with followers $(\mathrm{M}=4.24)$.

As for the organizational factors, company location plays role $(\mathrm{p}=0.004)$ in that leaders working in the Bratislava region $(M=4.90)$ attain higher levels of VOL than their counterparts from other Slovak regions $(M=4.33)$. There is a systematic difference also based on whether the company is owned by the state or a private owner $(p=0.000)$, with leaders working in state-owned companies lower in $\operatorname{VOL}(\mathrm{M}=3.97)$ and leaders working in private companies considerably higher in $\operatorname{VOL}(\mathrm{M}=4.87)$. There is no notable difference in whether the company is Slovak or foreign $(\mathrm{p}=$ 0.509). Nevertheless, leaders working in companies with foreign activities (export or sales to markets abroad) are significantly higher in $\operatorname{VOL}(\mathrm{M}=5.03, \mathrm{p}=0.000)$ than their counterparts $(\mathrm{M}=4.08)$. Company size is also a differentiator in respect to the VOL $(\mathrm{p}=0.018)$. The highest level of VOL was identified in micro companies with less than ten employees $(M=5.11)$, followed by medium and large companies ( $\mathrm{M}=4.74, \mathrm{M}=4.80$ respectively), whilst the lowest VOL score was obtained for leaders in small companies with up to 49 employees $(M=4.09)$.

\section{Discussion and implications}

The overall VOL score indicates that the perceived values orientation of leaders working in Slovak companies is somewhat medium high. This is in line with results of a prior leadership research in Slovakia on a sample of more than 800 managers. It was carried out based on the ELS tool (Brown et al. 2005) and showed that Slovak followers perceived their supervisors as ethical leaders on a slightly above average level with the mean value 5.07 measured on a seven-point scale (Lašáková et al. 2017). Although here the results of VOLQ with the mean value of 4.67 are less in favour of the leaders, it should be noted that the sample in the prior research based on ELS included only managerial personnel, whereas in this study also non-managerial respondents have participated, who could have a more critical stance to their supervisors.

Although the VOLQ is unidimensional, some interesting findings regard the differences between its five components. Leaders in Slovak companies are more altruistic and oriented to (self)development, and on the other hand, they are lower in self-reflection, authenticity and role modelling. These outcomes show that, to some extent, leaders are better at helping themselves and others to grow and in maintaining close friendly interpersonal relationships with followers. On the other side, leaders are less equipped in reflecting their own behaviour and how it shapes their image and is perceived by the other employees. To help their leaders, companies might implement specialized authenticity trainings for leaders. For instance, Ibarra (2015) suggests for leaders setting clear goals for personal learning and learning from taking charge of an unfamiliar role, from diverse role models, or from structured feedback including constructive critique. Nevertheless, in Slovak culture the latter might be particularly hard to digest due to a history of higher power distance that encourages facesaving behaviour in leaders. 
The analysis of systematic differences in the VOL level across various individual and organizational characteristics unveiled some unexpected findings. First, our results show the VOL level does not differentiate between female leaders and their male counterparts. This is somewhat surprising since a large proportion of the ethical leadership and decision-making literature suggests women are more ethically sensitive than men (e.g., Simga-Mugan et al. 2005, Herington and Weaven 2008, Oumlil and Balloun 2009, Chen et al. 2016). Similarly, also the cultural differences between the leader and the follower did not affect the results of the perceived VOL level. This is interesting since literature suggests culture could have predictive or explanatory power in this respect, for instance Stajkovic and Luthans (1997) propose a social cognitive model how national culture influences business ethical standards and individual moral development. Our results are promising in that the VOLQ tool might be free of cultural bias and could be used within diverse cultural settings. Nevertheless, this assumption needs thorough validation in future research.

Second, two variables are quite novel in ethical leadership research. The "length of leader-follower cooperation" and the "frequency of leader-follower interaction" both showed effect on the level of perceived VOL. Surprisingly, longer leader-follower relationships bring lower perceived VOL in leaders. This implies that the amount of time spent with the leader might affect negatively leader's perceived ethicality at work. Possible interpretation could be that the longer the employee collaborates with the leader, the more information and a more complete picture of the leader's personality the follower can obtain. Knowing a person really needs time. As the time passes by, the follower reveals differing personality facets of the leader with all the subtle nuances in behaviour, petite incongruences and potential ethical missteps, this leading to a more critical evaluation of leader's ethicality and values orientation. As for the other variable, "frequency of leader-follower interaction", literature provides some, although very limited, evidence on its effects. Deriving from the Antonakis and Atwater's (2002) study, it could be assumed that the leader-follower interaction frequency is related to the degree of ethical direction and feedback followers receive and that the lower frequency will be associated with higher distance between the leader and followers. In our study, leaders frequently interacting with followers are rated more favourable in terms of values orientation than leaders whose contact is occasional or almost non-existent. The VOL is partially based on authenticity, while according to Gardner et al. (2005a) the authenticity is in turn based on trust. Leader's frequent exposure toward followers might help to build trust (given that the leader is ethical). In another research on the effects of transformational leadership, Mulla and Krishnan (2012) proved that high frequency of leader-follower interaction enhanced the impact of transformational leadership on work ethics orientation of the followers. Likewise, our results suggest that in case leaders and followers interact more frequently, more opportunities raise for transferring leader's values toward followers.

Third, regarding the examined organizational factors, some of them proved to be related with the level of VOL in companies. While the regional differences in VOL between Bratislava region and the other Slovak regions were proved, the difference between Slovak and foreign-owned companies was not confirmed. This is in sharp contrast with the prior ethical leadership research, where authors inferred that despite substantial economic differences no significant disparities in ethical leadership between Slovak regions were found and that the foreign-owned companies exhibited substantially higher levels of ethical leadership than the Slovak-owned companies (Lašáková et al. 2017). Yet, here the VOL results are derived from a pilot study on a smaller number of participants and as such have to be confirmed in larger samples.

Fourth, notable finding regards the significant difference in VOL between state- and private-owned companies in Slovakia. If the owner is the state, or it is a public organization, respondents evaluate their leaders more critically and perceive them much less values oriented. This is in line with preliminary findings of Remišová et al. (2015) in that they posit the public sector in Slovakia is lagging behind the private sector in ethical leadership. In addition, besides the ethical leadership, their results indicate differences in favour of the leaders in private companies also in regard to the ethical decision-making as well as the level of knowledge leaders have in ethics. This gap in ethics between private and public organizations was noted also in previous research. For instance, Beeri et al. (2013:59) argue that the "need to eradicate corruption and improve the ethical standards of elected officials and public servants has become a major issue on the public agenda throughout the Western world". Likewise, Downe et al. (2016) point out that local government organizations are a vital focus for ethics research, given that they have considerable responsibility for distributing significant money from public funds. Svensson et al. (2009) showed that the private sector companies were more engaged with ethics management than the public sector entities. Public employees work in a complex and unstable environment, which is more prone to ambiguity and outside influences (Boyne 2002) and public managers face a more diverse set of stakeholders than private-sector managers (Tomescu and Popescu 2013). This puts their ethicality particularly under pressure. Importantly, the ethical leadership is likely to increase subordinate willingness to report ethical problems (Hassan et al. 2014). Considering the unflattering results on weak values orientation of public companies' leaders in this study, the human resource management in public 
organizations should focus especially on the ethical development of their leaders.

Finally, the differences in VOL based on the company size are intriguing, too. Results show quite high VOL scores were attributed to leaders in micro companies, whereas leaders in small companies were rated significantly worse than leaders in medium and large companies. We assume that in the sample the micro companies with less than ten employees were especially smaller family businesses or start-ups where the relationships with the leaders are often informal and the overall climate is unequivocally relaxed. This might contribute to the higher level of VOL in micro companies, as Kalshoven and Boon (2012) found in their research an informal work environment facilitates leader's potential for personalized approach to employees and that small team leaders rely more on the informal and somewhat less tangible ways of managing people based on personal role modelling. On the other hand, in case of larger companies in our sample with more than 50 employees, the higher level of VOL might be affected by implementation of ethics management infrastructures (systematic monitoring of unethical conduct, whistle-blowing channels/hotlines, ethics counselling, etc.) that are more often employed in larger companies than in the small ones. Interestingly, our results suggest that particularly small companies with ten to fifty employees are exposed to the risks associated with lower VOL. According to Spence (1999) small firms are controlled mostly by informal mechanisms, mistrusting bureaucracy and strained by multi-tasking. Small companies typically employ fewer specialists and thus the HRM or ethics management is marked by lower priority and eventually also lower professionalism. Our results show that small firms' owners should pay raised attention to sophisticated selection of leaders with clear ethical orientation. As formalized ethics tools (e.g., codes of ethics and ethical standards) are likely ineffective in small companies (Spence and Lozano 2000), the responsibility for creating and maintaining an ethical workplace is dependent on the moral awareness of small firms' owners and the values orientation of recruited leaders.

\section{Conclusions}

The leadership ethics-related research in Slovakia as well as in other CEE countries is somewhat neglected in the current literature. Therefore, we believe this pilot study might enhance the respective discourse and could serve as a methodological basis for future research of VOL. As it was part of a series of validation studies aimed at creating a reliable tool to measure VOL in companies, provided findings are just preliminary and should be considered with caution. Another limitation regards the given sample size jointly with the convenience-based way of gathering the data.
Despite the abovementioned limitations, this study provided some novel insights on the systematic differences in leaders' values orientation based on several individual and organizational factors. This forms a starting point in the field of comparative research of VOL in different social, economic and technological contexts. In addition, future research should employ representative samples with diverse cultural backgrounds to test the validity of the VOLQ tool in different countries. Moreover, given that VOL is still a relatively new concept in the current literature, future empirical studies should investigate its possible correlation with variables relating to employee performance such as job satisfaction, organizational commitment, or job involvement. Finally, in its current version, the VOLQ tool assesses leaders based on followers' observations that may lead to somewhat biased results. Yet, the majority of leadership tools rely on followers' perception and consequent judgement of leader's decisions and actions. Future research should establish a new version of the VOLQ tool as a self-reporting measure for leaders. Thus, the VOLQ's practical utilization could be enhanced, for instance in annual evaluation of leaders through the 360-degree feedback reviews.

\section{Acknowledgements}

The Values oriented leadership concept (VOL) was presented at the MHRO18 - Jubilee conference of the $5^{\text {th }}$ anniversary of the Strategic human resource management master studies at Ss. Cyril and Methodius University in Skopje, Faculty of Economics. Hereby authors would like to thank the conference participants for their valuable remarks and comments that helped to further elaborate on the clarification of the theoretical background of the VOL concept.

\section{Author contributions}

$\mathrm{AL}$ and IB were responsible for the theoretical conceptualization of the VOL. IB collected the empirical data. L'B and $\mathrm{AL}$ were responsible for interpreting the data presented in this article. AL wrote the first draft of the article and LB provided comments and revisions to it.

\section{Disclosure statement}

Authors of this study declare to have no competing financial, professional, or personal interests from other parties.

\section{References}

Antonakis J, Atwater L (2002) Leader distance: a review and proposed theory. The Leadership Quarterly 13 (6): 673-704. https://doi.org/10.1016/S1048-9843(02)00155-8

Argandona A (2012) Three ethical dimensions of the financial crisis. Working paper WP-944, January 2012 http://www.iese. edu/research/pdfs/di-0944-e.pdf 
Avey JB, Wernsing TS, Palanaski ME (2012) Exploring the process of ethical leadership: the mediating role of employee voice and psychological ownership. Journal of Business Ethics 107 (1): 21-34. https://doi.org/10.1007/s10551-012-1298-2

Avolio BJ, Gardner WL (2005) Authentic leadership development: getting to the root of positive forms of leadership. The Leadership Quarterly 16 (3): 315-338. https://doi.org/10.1016/j. leaqua.2005.03.001

Bai Y, Lin L, Liu JT (2017) Leveraging the employee voice: a multi-level social learning perspective of ethical leadership. The International Journal of Human Resource Management, 1-33. https://doi.org/10.1080/09585192.2017.1308414

Bandura A (1971) Social learning theory. New York: General Learning Press.

Barbuto JE, Wheeler DW (2006) Scale development and construct clarification of servant leadership. Group \& Organization Management 31 (3): 300-326. https://doi. org/10.1177/1059601106287091

Beeri I, Dayan R, Vigoda-Gadot E, Werner SB (2013) Advancing ethics in public organizations: the impact of an ethics program on employees' perceptions and behaviors in a regional council. Journal of Business Ethics 112 (1): 59-78. https://doi. org/10.1007/s10551-012-1232-7

Berger JB (2014) Leadership: a concise conceptual overview. Center for International Education Faculty Publications 18 https://scholarworks.umass.edu/cie_faculty_pubs/18

Blahunková I (2018) Hodnotovo orientované vedenie ludí. PhD's Thesis, Comenius University in Bratislava, Faculty of Management.

Boyne GA (2002) Public and private management: what's the difference? Journal of Management Studies 39 (1): 97-122. https://doi.org/10.1111/1467-6486.00284

Brown ME, Trevino L (2006) Ethical leadership: a review and future directions. The Leadership Quarterly 17 (6): 595-616. https://doi.org/10.1016/j.leaqua.2006.10.004

Brown ME, Trevino LK, Harrison DA (2005) Ethical leadership: a social learning perspective for construct development and testing. Organizational Behavior and Human Decision Processes 97 (2): 117-134. https://doi.org/10.1016/j.obhdp.2005.03.002

Chen Ch-I, Li Ch-I (2013) Assessing the spiritual leadership effectiveness: the contribution of follower's self-concept and preliminary tests for moderation of culture and managerial position. The Leadership Quarterly 24 (1): 240-255. https:// doi.org/10.1016/j.leaqua.2012.11.004

Chen C-W, Tuliao KV, Cullen JB, Chang Y-Y (2016) Does gender influence managers' ethics? A cross-cultural analysis. Business Ethics: A European Review 25 (4): 345-362. https://doi. org/10.1111/beer.12122

Copeland MK (2014) The emerging significance of values based leadership: a literature review. International Journal of Leadership Studies 8 (2): 105-135.

Dean KW (2008) Values-based leadership: how our personal values impact the workplace. The Journal of Values-Based Leadership 1 (1) http://scholar.valpo.edu/jvbl/vol1/iss1/9

Deluga RJ (1998) Leader-member exchange quality and effectiveness ratings: the role of subordinate-supervisor conscientiousness similarity. Group \& Organization Management 23 (2): 189-216. https://doi.org/10.1177/1059601198232006
Dierksmeier C (2016) What is 'humanistic' about humanistic management? Humanist Management Journal 1 (1): 9-32. https://doi.org/10.1007/s41463-016-0002-6

Downe J, Cowell R, Morgan K (2016) What determines ethical behavior in public organizations: is it rules or leadership? Public Administration Review 76 (6): 898-909. https://doi. org/10.1111/puar.12562

Eisenbeiss SA (2012) Re-thinking ethical leadership: an interdisciplinary integrative approach. The Leadership Quarterly 23 (5): 791-808. https://doi.org/10.1016/j.leaqua.2012.03.001

European Commission (2009) Presidents of Commission and Parliament discuss ethical contributions for European and global economic governance with European faith leaders. Press release database, Brussels, 11 May 2009 http://europa. eu/rapid/press-release_IP-09-730_en.htm

Freeman RE, Auster ER (2011) Values, authenticity, and responsible leadership. Journal of Business Ethics 98 (S1): 15-23. https://doi.org/10.1007/s10551-011-1022-7

Fry LW (2003) Toward a theory of spiritual leadership. The Leadership Quarterly 14 (6): 693-727. https://doi.org/10.1016/j. leaqua.2003.09.001

Gardner WL, Avolio BJ, Luthans F, May DR, Walumbwa FO (2005a) "Can you see the real me?" A self-based model of authentic leader and follower development. The Leadership Quarterly 16 (3): 343-372. https://doi.org/10.1016/j. leaqua.2005.03.003

Gardner W, Avolio BJ, Walumbwa FO (2005b) Authentic leadership theory and practice: origins, effects and development. Bingley: Emerald Group Publishing Limited.

Gardner WL, Cogliser CC, Davis KM, Dickens MP (2011) Authentic leadership: a review of the literature and research agenda. The Leadership Quarterly 22 (6): 1120-1145. https:// doi.org/10.1016/j.leaqua.2011.09.007

Graen GB (1976) Role making processes within complex organizations. In: Dunnette MD (Ed) Handbook in industrial and organizational psychology. Chicago: Rand-McNally, 1201-1245.

Graen GB, Uhl-Bien M (1995) Relationship-based approach to leadership: development of leader-member exchange (LMX) theory of leadership over 25 years: applying a multi-level multi-domain perspective. The Leadership Quarterly 6 (2): 219-247. https://doi.org/10.1016/1048-9843(95)90036-5

Hassan S, Wright BE, Yukl G (2014) Does ethical leadership matter in government? Effects on organizational commitment, absenteeism, and willingness to report ethical problems. Public Administration Review 74 (3): 333-343. https://doi. org/10.1111/puar.12216

Herington C, Weaven S (2008) Improving consistency for DIT results using cluster analysis. Journal of Business Ethics 80 (3): 499-514. https://doi.org/10.1007/s10551-007-9451-z

Ibarra $H$ (2015) The authenticity paradox. Harvard Business Review, January-February 2015 https://hbr.org/2015/01/theauthenticity-paradox

Jordan J, Brown ME, Treviño LK, Finkelstein S (2013) Someone to look up to: executive-follower ethical reasoning and perceptions of ethical leadership. Journal of Management 39 (3): 660-683. https://doi.org/10.1177/0149206311398136 
Kalshoven, K, Boon CT (2012) Ethical leadership, employee wellbeing, and helping. Journal of Personnel Psychology 11 (1): 60-68. https://doi.org/10.1027/1866-5888/a000056

Kalshoven K, Den Hartog DN, De Hoogh AHB (2011) Ethical leadership at work questionnaire (ELW): development and validation of a multidimensional measure. The Leadership Quarterly 22 (1): 51-69. https://doi.org/10.1016/j. leaqua.2010.12.007

Kraemer HMJ (2011) From values to action: the four principles of values-based leadership. San Francisco: Jossey-Bass.

Lašáková A, Remišová A, Búciová Z (2015) Teoretická reflexia etického vedenia ludí [Theoretical reflection of the ethical leadership]. In: Aktuálne problémy podnikovej sféry 2015. Bratislava: Ekonóm, 348-357 http://fpm.euba.sk/www_write/ files/veda-vyskum/Zborniky-APPS/2015.pdf

Lašáková A, Remišová A, Kirchmayer Z (2017) Are managers in Slovakia ethical leaders? Key findings on the level of ethical leadership in the Slovak business environment. Periodica Polytechnica Social and Management Sciences 25 (2): 87-96. https://doi.org/10.3311/PPso.9758

Lebow R, Simon WL (1997) Lasting change: the shared values process that makes companies great. Hoboken: John Wiley and Sons.

Liden RC, Sparrowe RT, Wayne SJ (1997) Leader-member exchange theory: the past and potential for the future. In: Ferris GR (Ed) Research in personnel and human resources management volume 15. Elsevier Science/JAI Press, 47-119.

Liden RC, Wayne SJ, Zhao H, Henderson D (2008) Servant leadership: development of a multidimensional measure and multi-level assessment. The Leadership Quarterly 19 (2): 161-177. https://doi.org/10.1016/j.leaqua.2008.01.006

Maak T, Pless NM (2006) Responsible leadership in a stakeholder society - a relational perspective. Journal of Business Ethics 66 (1): 99-115. https://doi.org/10.1007/s10551-006-9047-Z

Mayer DM, Kuenzi M, Greenbaum R, Bardes M, Salvador R (2009) How low does ethical leadership flow? Test of a trickle-down model. Organizational Behavior and Human Decision Processes 108 (1): 1-13. https://doi.org/10.1016/j. obhdp.2008.04.002

Mulla ZR, Krishnan VR (2012) Transformational leadership and Karma-Yoga: enhancing followers' duty-orientation and indifference to rewards. Psychology and Developing Societies 24 (1): 85-117. https://doi.org/10.1177/097133361102400104

O'Toole J (2008) Notes toward a definition of values-based leadership. The Journal of Values-Based Leadership 1 (1) http:// scholar.valpo.edu/jvbl/vol1/iss1/10

Oumlil AB, Balloun JL (2009) Ethical decision-making differences between American and Moroccan managers. Journal of Business Ethics 84 (4): 457-478. https://doi.org/10.1007/ s10551-008-9719-y

Pless NM, Maak T (2011) Responsible leadership: pathways to the future. Journal of Business Ethics 98 (S1): 3-13. https:// doi.org/10.1007/s10551-011-1114-4

Prilleltensky I (2000) Value-based leadership in organizations: balancing values, interests, and power among citizens, workers, and leaders. Ethics \& Behavior 10 (2): 139-158. https:// doi.org/10.1207/S15327019EB1002_03
Remišová A, Búciová Z, Lašáková A (2015) Ethical leadership in the public and private sector in Slovakia: a comparative study. In: Leadership and governance OF and IN public and private organizations in CEE countries: Abstract Reader. Chemnitz: Chemnitz University of Technology, 4-9 https:// www.researchgate.net/publication/282154559_Ethical_Leadership_in_the_Public_and_Private_Sector_in_Slovakia_A_ Comparative_Study

Remišová A, Lašáková A, Rudy J, Sulíková R, Kirchmayer Z, Fratričová J (2016) Ethical leadership in the Slovak business environment. Praha: Wolters Kluwer.

Schein EH (2010) Organizational culture and leadership. San Francisco: Jossey-Bass.

Schwartz MD, Dunfee TW, Kline MJ (2005) Tone at the top: an ethics code for directors? Journal of Business Ethics 58 (1-3): 79-100. https://doi.org/10.1007/s10551-005-1390-y

Sendjaya S, Sarros JC, Santora JC (2008) Defining and measuring servant leadership behaviour in organizations. Journal of Management Studies 45 (2): 402-424. https://doi.org/10.1111/ j.1467-6486.2007.00761.x

Simga-Mugan C, Daly BA, Onkal D, Kavut L (2005) The influence of nationality and gender on ethical sensitivity: an application of the Issue-contingent model. Journal of Business Ethics 57 (2): 139-159. https://doi.org/10.1007/s10551-004-4601-z

Spence LJ (1999) Does size matter? The state of the art in small business ethics. Business Ethics: A European Review 8 (3): 163-174. https://doi.org/10.1111/1467-8608.00144

Spence LJ, Lozano JF (2000) Communicating about ethics with small firms: experiences from the U.K. and Spain. Journal of Business Ethics 27 (1-2): 43-53. https://doi.org/10.1007/97894-011-4311-0_6

Stajkovic AD, Luthan F (1997) Business ethics across cultures: a social cognitive model. Journal of World Business 32 (1): 17-34. https://doi.org/10.1016/S1090-9516(97)90023-7

Svensson G, Wood G, Callaghan M (2009) Cross-sector organizational engagement with ethics: a comparison between private sector companies and public sector entities of Sweden. Corporate Governance 9 (3): 208-297. https://doi. org/10.1108/14720700910964343

Tomescu M, Popescu MA (2013) Ethics and conflicts of interest in the public sector. Contemporary Readings in Law and Social Justice 5 (2): 201-206.

Trevino LK, Brown M (2005) The role of leaders in influencing unethical behavior in the workplace. In: Kidwell RE, Martin CL (Eds) Managing organizational deviance. Sage Publications, 69-79 https://us.corwin.com/sites/default/files/upmbinaries/4910_Kidwell_Chapter_3.pdf

Trevino LK, Brown M, Hartman LP (2003) A qualitative investigation of perceived executive ethical leadership: perceptions from inside and outside the executive suite. Humane Relations 56 (1): 5-37. https://doi.org/10.1177/0018726703056001448

Trevino LK, Hartman LP, Brown M (2000) Moral person and moral manager: how executives develop a reputation for ethical leadership. California Management Review 42 (4): 128-142. https://doi.org/10.2307/41166057

Uhl-Bien M, Carsten MK (2007) Being ethical when the boss is not. Organizational Dynamics 36 (2): 187-201. https://doi. org/10.1016/j.orgdyn.2007.03.006 
Van Dierendonck D, Nuijten I (2011) The servant leadership survey: development and validation of a multidimensional measure. Journal of Business Psychology 26 (3): 249-267. https://doi.org/10.1007/s10869-010-9194-1

Voegtlin Ch, Patzer M, Scherer AG (2012) Responsible leadership in global business: a new approach to leadership and its multi-level outcomes. Journal of Business Ethics 105 (1): 1-16. https://doi.org/10.1007/s10551-011-0952-4
Wang Y, Kleiner BH (2005) Defining employee dishonesty. Management Research News 28 (2/3): 11-22. https://doi. org/10.1108/01409170510785057

Weaver GR, Trevino LK, Agle B (2005) "Somebody I look up to": ethical role models in organizations. Organizational Dynamics 34 (4): 313-330. https://doi.org/10.1016/j.orgdyn.2005.08.001 